\title{
Division of Matrimonial Assets under the Tanzania Marriage Law
}

\author{
By B. A. Rwezaura
}

\section{Introduction}

The decision of Mapigano J., in the case of Zawadi Abdallah v. Ibrahim Iddi ${ }^{1}$ has brought into sharp focus two conflicting legal interpretations of section 114 of the Law of Marriage Act 1971. This section empowers courts to order the division of matrimonial assets when granting or subsequent to the grant of a decree of separation or divorce. For ease of reference, the provisions of section 114 are reproduced below.

S. 114(1) The court shall have power, when granting or subsequent to the grant of a decree of separation or divorce, to order the division between the parties of any assets acquired by them during the marriage by their joint efforts or to order the sale of any such asset and the division between the parties of the proceeds of sale.

(2) In excercising the power conferred by subsection (1), the court shall have regard -

(a) to the custom of the community to which the parties belong;

(b) to the extent of the contributions made by each party in money, property or work towards the acquiring of the assets;

(c) to any debts owing by either party which were contracted for their joint benefit; and

(d) to the needs of the infant children, if any of the marriage, and subject to those considerations, shall incline towards equality of division.

(3) For the purposes of this section, references to assets aquired during a marriage include assets owned before the marriage by one party which have been substantially improved during the marriage by the other party or by their joint efforts.

The relevant part of the section which concerns the present discussion is the legal interpretation of the term "joint efforts" which the spouses pull together towards the acquisition of assets. According to subsection 2 (b) of section 114, a spouse's contribution towards the acquisition of such assets can be in form of money, property, work or a combination of all these. Where one of the spouses has made monetary contribution towards the acquisition of the assets, the spouse's right to a share of the relevant assets has not been disputed by the courts and it is generally agreed that, so far as it is possible 
to calculate, such spouse will be entitled to a share which corresponds to the extent of that spouse's contribution.

It is mainly where a spouse, usually the wife, has made contribution solely in the form of housework that judges have expressed diverging opinions. Some judges have expressed the view that a wife whose contribution is in form of housekeeping and childcare has no legal right to a share in the property accumulated during the marriage. Others have held that such a wife is entitled to a share in the assets and have interpreted the relevant provisions of the law to include domestic work.

The purpose of this paper is to put a number of question marks on the reasons given by Mapigano J., to support his holding in the case of Zawadi Abdallah. In doing this I hope to offer what I consider to be a correct interpretation of section 114 of the Law of Marriage Act.

\section{The Case of Zawadi Abdallah}

The facts of this case were fairly straightforward. The parties were married for a period of twenty-one years and there were seven children of the marriage. Their marriage was terminated by the Morogoro Urban Primary Court. Thereafter the former wife, Zawadi Abdallah, applied at the Morogoro District Court for decision of matrimonial assets which included two houses and a lorry. In support of her claim she argued that it was through her industry and prudence in the keeping of the household that the husband was able to save a handsome amount of money with which he used to build the two houses. She further claimed that she had assisted her husband in managing a retail shop from which the husband obtained the necessary resources for purchasing the lorry.

These claims were resisted by the husband, Ibrahim Iddi, who told the court that his wife had not assisted at all in running the shop. He called two witnesses who identified themselves as his shop-assistants and gave evidence in his favour. The husband also disputed the wife's claim that her role as a prudent and austere house-wife had enabled him to acquire the relevant assets. He stated that his wife was at all material times receiving adequate maintenance. More significant however, was the husband's evidence that he had acquired the said property through a loan given to him by his employer, a substantial part of which remained unpaid.

Having considered the entire evidence the District Court held that the properties were acquired using the loan from the employer and that the claimant was just a housewife who had a perfectly happy life. The court noted that "the performance by the wife of her normal domestic chores was not an effort or contribution within the meaning of section 114 of the Law of Marriage Act and was therefore not a relevant factor in considering the question of division of matrimonial assets".

Zawadi Abdallah appealed to the High Court where it was held that the property at issue was acquired by the husband, using the employer's loan and that since the greater part of the loan remained unpaid, such property was more of a liability than an asset. The 
appellate court then considered the question whether the wife was entitled to any share in the property acquired during marriage merely by reason of being a housewife. The court held that the District Court was right in holding the view that housework was not to be equated with the husband's work for the purpose of evaluating contributions made by spouses towards the acquistition of property. In his concluding remarks, Mapigano J., noted that section 114 was not intended to confer to a married woman who did not have property or had failed to acquire any during marriage because of household duties, a share in the property acquired by her husband during the subsistence of the marriage. Therefore, he dismissed the appeal and advised the former wife to consider seeking alimony vide section 115 (1) (e) of the Law of Marriage Act.

\section{Two Schools of Thought}

In the course of his judgement Mapigano J., stated that there were, in the Judiciary, two schools of thought - the conservative and the liberal. The first school consisted of those who maintain that under section 114 the term 'joint efforts' is limited to direct contribution by a spouse in form of money, property and work to the acquisition of the assets in question and that housekeeping and childcare do not count at all. In that school is to be found Patel J., who held over five years ago in the case of Hamid Amir v. Maimuna Amir ${ }^{2}$ that the term 'joint efforts do not include domestic services rendered by a wife and that in any case had the Legislature intended that such services be counted as a contribution which entitles a wife to a share in the property acquired during marriage, it would have said so in plain language.

The liberal school on the other hand hold the opposite view, arguing for a broad construction that housework and childcare must be regarded as part of the joint efforts or contribution towards the acquisition of any asset by the husband. In support of this view they stress the fact that in principle there is no real distinction between a wife who takes up paid employment and brings money into the family or carries on business or practises a profession and one who remains at home to devote all her time to the management of the household. In this latter school is to be found Makame J., who held in the case of Rukia Diwani Konzi v. Abdallah Issa Kihenga ${ }^{3}$ that the provisions of section 114 are wide enough to cover a wife's domestic services and hence to entitle her to a share in the property acquired during her marriage. Makame J., noted that Tanzania law could not afford to ignore a very large number of wives who stay at home to care for the family, adding that, "even in a country like Britain, where salaried married women are quite common, the modern progressive view with which I wish to associate myself, is that looking after the home and bringing up the children is a valuable contribution". 


\section{The Risk of Being Deemed a Conservative}

"At the risk of being deemed a conservative, though I would like to believe that I am not", observed Mapigano J., "I must say that on the view that I take of the law I feel compelled to pronounce that the decision of the learned Magistrate is .. . sound". This would appear to be a case of a judge who thinks that his hands are tied and much as he may wish to arrive at a different conclusion he cannot do so. Throughout the entire judgement, the appellate judge consistently presented arguments on both sides and made it very clear that he would be happy to join the liberal school if only he could be convinced that the law was different from what he thought it was. Indeed in the penultimate paragraph of his judgement Mapigano J., stated that his decision should not be taken to mean that he approved of the law which ignores the domestic services of the wife nor did he wish to deny the fact that one of the ills of the breakdown of marriage was the economic hardship that housewives have to suffer, particularly in Tanzania where the woman does not accumulate any personal property. "I think therefore", he concluded, "there is much to commend the liberal viewpoint to serious reflection, and consideration".

The primary question which must be raised here is whether the judge was right in thinking that his hands were tied and that only the change in the law would untie them. He gave four grounds for his decision all of which taken together lead to the conclusion that section 114 of the Law of Marriage Act does not say that a wife's domestic services are a contribution which at law entitles her to a share in the property accumulated during the life of the marriage. A summary of these grounds is given below after which follows more detailed consideration.

The first ground given by Mapigano J., is that if the liberal interpretation of section 114 were to be followed, it would lead to more complex legal questions on which the legislature has not given any guidance. For example, should the wife who has caused the breakdown of the marriage "be allowed to benefit from a marriage which she has wrecked?", the judge inquired. Another difficulty would be to determine the relationship between an order for division of assets under section 114 and another order for alimony which the court has discretion to make under section 115 of the Law of Marriage Act. The second ground was that the plain meaning of section 114 did not permit the interpretation given to it by the liberal school and that it was not part of Tanzania law before the enactment of the Law of Marriage Act. Under these circumstances, the judge wondered whether this was a fit case in which the court ought to interpret the law innovatively with the view to making it responsive to societal needs and aspirations. Although agreeing in principle that such judicial approach was generally accepted in many countries of the Common Law system, he thought however, that judicial activism must not be allowed to "encroach on the province of the Legislature".

The third ground was that if he were to follow the liberal interpretation, that approach would amount to introducing into the statute the concept of community of property when in fact other provisions of the legislation "reflect the notion of separate property". 
The fourth and final ground given by Mapigano J., is that the background material relating to the enactment of the Act "strongly point to a definite legislative intention that domestic services should not count when the court is dealing with the matter of division of assets under section 114 ".

\section{The Principle Underlying Division of Assets}

The legal principle on which division of matrimonial assets is based is one of giving recognition to the contribution of the spouse towards the acquistion or enhancement of value of the particular property. Let us take the fact situations in which the principle of division was accepted by the appellate judge himself. Mapigano J., gave three instances which he considered to be common and to which he conceded that the provisions of section 114 would apply. The first is where both spouses make direct contributions to the purchase of the property or to the building of an estate. The second instance in where both spouses take up employment or engage in trade and by arrangement between them one uses his or her earnings to meet the expenses of the household such as meeting grocery bills and purchasing clothes for the children while the other spouse applies his income to build up an estate. The third situation is where spouses open a joint bank account into which they remit all their incomes and from which they draw to meet household expenses and to invest.

In all the foregoing fact situations an spouse makes direct monetary contribution towards the acquisition of the family assets. Division of property in such cases is intended to compensate the other spouse for his or her contribution. It would appear therefore that the only distinction between the three situations and one in which a spouse stays at home to care for the family without making a direct financial contribution is simply one based on the refusal by the court to attach monetary value to housework. Yet in a money economy such as that of Tanzania or indeed of any country the distinction between money and services, especially where the latter can be freely bought or sold, is false. On this ground alone, a housewife has a right under section 114 to a share in the property acquired during her marriage. Her housework saves the money for the family which would otherwise go to meet the salaries of a housekeeper and a nanny. So far as housewives are concerned, the foregoing examples apply mostly to urban women married to working men. As I shall point out later, rural housewives, who are engaged in agriculture, produce food and cash crops and their entitlements under section 114 must be examined separately.

Therefore, if it is accepted that the principle of division of property between spouses is based on the legal recognition of one's actual contribution towards the acquisition of such assets, then the question of which party caused the breakdown of the marriage is an irrelevant consideration. This matter was considered by the Parliament during the debates on the Law of Marriage Bill. Some MPs expressed the view that a wife who causes the breakdown of the marriage ought not to be given a share in the assets. $\mathrm{Mr}$. 
Kawawa, Leader of the Government business in the House, replied that "the right of a spouse to a share of assets must be clearly understood because it does not depend upon which party caused the breakdown of the marriage. What is being given to the spouse is an entitlement based on sweat and not on good behaviour" (1971: 380) (Trans. BAR.). Samatta J., expressed a similar view in the case of Swiga Kilima v. Hamisi Mwakafila ${ }^{4}$ where he stated that there were no provisions in the Law of Marriage Act which state that a spouse who is responsible for the breakdown of the marriage loses his or her share of the assets which the spouses acquired through their joint efforts. Samatta J., stressed that "whether the provisions of section 114 are read by the use of a magnifying glass or a microscope, it is patently clear that a spouse cannot lose his or her share of matrimonial assets because he or she is the one who caused the burial of the marriage".

On the relationship between an order for division of assets and an order for maintenance made under section 115 , the following points will be made. The principles on which the two orders are based differ in that the order for division of assets is based on the principle of compensation while that of maintenance is based on a statutory obligation imposed on the spouse who has the means and ability to maintain the other. The relevant parts of section 115 state that:

115. (1) The court may order a man to pay maintenance to his wife or former wife

(a) if he has refused or neglected to provide for her as required by section 63;

(b) if he has deserted her, for so long as the desertion continues;

(c) during the course of any matrimonial proceedings;

(d) when granting or subsequent to the grant of a decree of separation;

(e) when granting of subsequent to the grant of a decree of divorce;

(f) where the parties were married in Islamic form, for the customary period of iddat following the date on which the divorce takes, or is deemed to have taken, effect;

(g) if, after a decree declaring her presumed to be dead, she is found to be alive;

Provided that where the marriage has been dissolved, the wife shall not, unless the court for special reason so directs, be entitled to maintenance for herself for any period following the date when the dissolution takes effect.

A similar statutory duty to maintain a husband is imposed on the wife under section 115

(2) where due to incapacitation a husband is unable to earn a livelihood. In either case the means of the paying spouse and the needs of the recipient spouse are important considerations which the court has to consider before making an order for maintenance. It would appear from the foregoing that an order made under section 115 does not depend upon the contribution of a spouse, rather, upon the status of being married and upon the needs of that spouse. The burden of proving that the spouse needs maintenance and that the other has the means to supply the same has been placed by statute upon the 
petitioner. ${ }^{5}$ It is possible therefore that a wealthy wife who cannot succeed in an action for personal maintenance against her not so rich husband can still recover her share in the property jointly acquired. In a deserving case therefore, a divorced wife can secure an order for maintenance as well as one for division of assets.

Bearing the above in mind, it can be said that the relationship between the two orders is that where division of assets has the effect of putting the receiving spouse in a position of a person of means, it will disentitle that spouse from receiving maintenance under section 115. By the same token, if such division of assets has the effect of taking away the means of the paying spouse, here again that spouse will be exempted from maintaining the other even if that other spouse can prove the need for maintenance. This, I believe, disposes the first ground for the decision.

It is convenient to deal now with the third ground before tackling the second and the fourth. As stated earlier, Mapigano J., was of the opinion that were he to interpret section 114 in the same manner as the liberal school, such interpretation would amount to introducing into the law a new concept of community of property when the rest of the statute dealing with property provides for separation of property. ${ }^{6} \mathrm{He}$ cited sections 58 and 60 of the Law of Marriage Act both of which deal with separation of property. Section 58 provides that -

"Subject to the provisions of section 59 (relating to the matrimonial home) and to any agreement to the contrary that the parties may make, a marriage shall not operate to change the ownership of any property to which either the husband or the wife may be entitled or to prevent either the husband or the wife from acquiring, holding and disposing of any property."

Section 60 creates rebuttable legal presumption in favour of one spouse as the sole owner where the property acquired during marriage is registered in the name of that spouse. And where the property is registered in the spouses' joint names, the presumption is that such property belongs to them jointly and in equal shares.

I agree with Mapigano J., that the above provisions clearly establish separate ownership of property between married people. The question then is whether there is a contradiction between the principle of separate ownership of property and the legal recognition of a wife's domestic services as constituting a contribution to the acquisition of family assets. If it is accepted that the principle underlying division of property is one of compensation, it does make any difference whether what is being compensated is direct monetary contribution or domestic services. Indeed it seems to me that a law which recognises a spouse's contribution in any form and protects that spouse's share in the

5 See Zubeda Daudi v. Alimia Inusimia 1978 LRT n. 7 and Judith Mfunga v. Titus Lugangira (MZ) High Court (PC) Civ. App. No. 151 of 1974 (unreported) (Lugakingira J.).

6 The concept of separation of property can be traced from the English 19th century Married Women Property Act (1882). Its essential aspect is that marriage has no effect on the property rights of spouses, whether such property is acquired before or af ter marriage and that each spouse has unfettered right to deal with his or her property in any manner whatsoever. 
family assets at the time of separation or divorce, reflects the true spirit of the principle of separate property.

It is not clear to me why the appellate judge thought the application of section 114 to domestic services amounted to introducing the concept of communio bonorum. One possible lead to the judge's thinking appears on the third page of the judgement where he notes that "subsection (2) of section 114 sets out factors which the court must consider when exercising its powers under section 114 (1)". Then he remarked that in any case "subsection (2) only comes into play when it has been established that the property in question is jointly owned by the parties i. e. that the asset was acquired by their joint efforts during the subsistence of the marriage". If this is the paragraph which accounts for the judge's third ground, then my understanding of the section differs from that of the appellate judge. First of all, I think that it is not a condition precedent that any property acquired by the spouses during their marriage be "jointly owned" before subsection (2) of section 114 can be applied. All that is necessary is proof of contribution however small. Secondly, "joint efforts" need not always lead to ownership of equal shares in the acquired assets. Indeed it is precisely for the fact that spouses may own unequal shares in the assets that section 114 (2) requires the court, when exercising its powers under that section, to have regard to the extent of the contribution made by the parties so that each spouse may be awarded a fair share.

Therefore, it cannot be said that the recognition under section 114 of the wife's domestic services as a contribution amounts to introducing in the law the principle of communio bonorum.

\section{The Intention of the Legislature}

In his various efforts to map out the exact interpretation of section 114 , the appellate judge invoked the principle of statutory interpretation whereby the meaning of a statutory provision can be ascertained by reference to the intention of the Parliament. In the present case Mapigano J., relied on the Kenya Report of the Commission on the Law of Marriage and Divorce (hereinafter called the Spry Report). Although one expects to 'discover the intention of parliament by examining parliamentary debates, it has also been accepted that law commissions' reports are useful additional sources for this purpose. This approach was approved for England ten years ago by Lord Denning M. R. who stated in the case Wachtel v. Wachtel' that it "has sometimes been suggested that we should not have regard to the reports of the Law Commission which lead to legislation. But we think we should. They are most helpful in showing the mischief which Parliament intended to remedy."

Turning now to the Tanzania situation and even assuming that Lord Denning's dictum is of persuasive value in Tanzania, can it be said that the intention of the Tanzania 
Parliament can be gathered from a law commission's report of another state? According to Mapigano J., the Law of Marriage Act "is based on the work of the Kenya Commission's report ... (and) borrows heavily from the draft bill prepared by the said Commission". Mapigano J., is well aware that the Spry Report cannot be treated as authority but, as he put, "I find it valuable because it provides that background to our law and helps to discover the intention of the legislature. I think I can treat that background as indicating that our Legislature adopted the ideas and philosophy contained in that report." Those who have read the Spry Report will no doubt agree that the Tanzania Parliamentary Draftsman adopted a substantial part of the draft bill. One remembers the words of Professor James S. Read who referred to it as "an interesting example of East African interdependence" (1972:19).

Whereas it is true that the Draftsman read the Spry Report, I very much doubt whether the Tanzania National Assembly ever had an opportunity to consider the Spry Report. As I will show shortly, the Tanzania Parliament debated the provisions of section 114 and expressed its views thereon.

It is essential to add here that even if one were to accept the argument that the intention of the Tanzania Parliament can be gathered from the Spry Report or even that the Legislature endorsed the views of the Commission when it adopted the draft bill, I submit that in any case the appellate judge did not base his opinion on the pertinent paragraph of the Report on which section 114 was based. He looked at paras 177-184 which discuss the question whether community of property or separation of property system be adopted in Kenya and the question of the spouse's rights in the matrimonial home. The Commission rejected the system of community of property on the ground that it was complex and unsuitable to the circumstances of Kenya (Para 180 at p. 55). But although the Commission rejected the concept of community of property they were not opposed to the idea that domestic services of a wife be counted as joint efforts in determining a wife's share in the property acquired during marriage. This idea may be gathered from para 179 of the Report where the Commission noted that -

"At first sight, there is much that is attractive in the idea of community of property between husband and wife particularly as regards property acquired during the marriage. In urban society, both husband and wife may be wage-earners and even where the husband is the sole wage earner, any savings may be largely attributable to the industry and prudence of the wife in running the household. In rural society, the wife usually does much of the work of the shamba. It seems fair, therefore, that the wife should share in the fruits." (emphasis BAR)

The idea of compensation for the spouse's contribution is picked up later in para 338 where the Commission stated that they did not think that "either husband or wife should be left without a remedy on divorce where assets which he or she has contributed are vested in the other..."This is the paragraph on which the Tanzania section 114 was based. It must be noted also that the Commission rejected the idea of providing a definition for the terms "joint efforts" and "contribution" and left the matter to the courts to decide in the light of the circumstances of each case. Therefore, it is accurate to 
say that the Commission did not wish to commit itself by providing a definition of these terms which are the key words in section 114 of the Law of Marriage Act. There ist nowhere in the Spry Report where the Commission rejected the right of a housewife to a share in the property acquired during marriage. ${ }^{8}$

Turning now to the Parliamentary debates of the Tanzania National Assembly, much can be gathered from there which bears on the intention of the Legislature. ${ }^{9}$ The provisions of section 114 did not pass without much debate. Some MPs opposed it strongly while others supported it adding emphasis to the importance of housework and childcare. For example, Hon. Mrs. Milembe stated that domestic work was just as important for the smooth functioning of the family as the money which the husband earns from his job. The Honourable MP added that

"When the husband goes to the office he leaves his wife at home busy looking after the children ad doing household chores such as washing, cooking, and generally managing the entire household. Therefore, in my opinion, housework is more valuable for the family than the husband's office work" (laughter) (1971:91).

After much debate on the question of division of assets and the contribution of the wife, the Second Vice-President Mr. Rashidi Kawawa, took the floor and summarized the debate concluding that may MPs had raised the question of division of assets at the time of separation of divorce and referred to the question raised by an MP who had wondered whether or not a wife who on her marriage found some of her husband's cattle expecting calves would be entitled to a share in the calves. In his reply to this hypothetical case $\mathrm{Mr}$. Kawawa said that "if that wife participated in looking after the pregnant cows, she would surely be entitled to a share in the resulting calves. But if she did not assist in looking after them, she would not be entitled to any share in the calves" (1972:380). From these debates therefore, one gathers a feeling that housework was considered to be an important contribution which ought to count towards the division of property during marriage.

Finally, a few remarks must be made concerning judicial policy about which Mapigano J., made some observations. The appellate judge agreed with the view that law ought to be interpreted by courts in an innovative way so as to make law responsive to societal aspirations. Nonetheless he was not convinced that the case before him was a proper one in which this principle could be applied. The reason he gave was that section 114 was not ambiguous. It clearly excluded the domestic services of a wife as an element of the couple's joint efforts towards the acquisition of family assets. Therefore, if he were to interpret that section in the same way as the liberal school does, such an approach would amount to an encroachment on the Legislative function of Parliament. Yet as this paper

8 But see para 339 where the Spry Commission appears to suggest that contribution ought to be more than the spouses normal matrimonial duty. This opinion was based on the state of case Law in England decided bef ore 1970 and especially that relating to spouses rights in the matrimonial home.

9 See for example the speeches of Hon. Nungu (1972: 81); Hon. Mabawa (1972:360-61); Hon. Alhaj Nyembo (1972: 99-100); Hon. Wassira (1972:131-132); and Hon. Bwanga (1972:169). 
has tried to show, the provisions of section 114 do not clearly exclude a wife's domestic services in determining the extent of her contribution to the acquisition of family assets.

\section{The Concept of Wifely Duties}

The idea of 'wifely duties' which Mapigano J., did not discuss but which was raised by the trial court, is important and must be clarified. In rejecting the application of a wife for division of property the trial court followed the decision in Hamid Amir v. Maimuna Amir ${ }^{10}$ in which Patel J., stated that the performance by a wife of her normal domestic chores was not an effort or a contribution within the meaning of section 114 of the Law of Marriage Act and counted for nothing at law in considering the question of division of assets. The trial court noted further that the reason for not counting a wife's domestic services was because housework is a "wifely duty"; that is, a "customary obligation of a wife, just as her maintenance was the customary obligation of the respondent as a husband". This is a significant point which could have influenced Patel J., in the case of Amir.

Perhaps I should say here that one aspect of the Law of Marriage Act which will continue to give trouble to courts for many years to come is the Act's constant reference to customs of the parties as a relevant factor to be considered by the court in a variety of circumstances. ${ }^{11}$ The implications of this requirement is that courts are expected to draw insights from customs and traditions which evolved during the pre-colonial period and which are increasingly becoming obsolete, if not sometimes oppressive. The concept of wifely duties which appears to originate from traditions and custom ${ }^{12}$ has been applied to deprive wives their shares in the family assets. ${ }^{13}$

Courts also cannot ignore the basic principles of English family law on which the old marriage law of Tanzania was based and which is also substantially reflected in our contemporary family law. Therefore, since the Law of Marriage Act represents a combination of the two systems of law, courts may have to look to both systems for their guidance without necessarily being bound to either of them. I think Mr. Kawawa put it correctly when he said in Parliament that customs and traditions of the parties will have to be followed in the division of property "but those customs which provide for depriving one spouse, especially the wife, her rightful share, will not be applied" (1971:381). The origin of the concept of wifely duties appears to be closely related to the African traditional assumption underlying marriage. Among the patrilineal communities of Tanzania, a valid marriage was contracted after the transfer of sufficient amount of

101977 LRT n. 55.

11 See for example ss. 74 (2) (a); 107 (1) (a); 114 (2) (a); 125 (2) (c).

12 Certain customary rules provide that payment of bridewealth enables a husband to acquire rights in his wife which include her labour power.

13 See for example Iddi d/o Kunganya v. Ali Mpate (1967) HCD No. 49. 
bridewealth from the family of the husband to that of the wife. Through marriage a husband (and his lineage) acquired definite rights in the wife. These included the right to the wife's reproductive potential, the right to sexual access and to her services. A wife was thus expected to bear children for her husband, to meet his sexual needs and to manage the household as best she could. She also produced and processed food for the family. In practice therefore, ist was the wife who traditionally maintained her husband and the children even though in law it was her husband who has control over the land on which food was produced. In general therefore, a statement to the effect that it was a customary obligation for a husband to maintain the wife leaves a lot unsaid.

Another feature of the traditional period which must be noted is the fact that the traditional economy was based on subsistence production and given its technological level, accumulation was small and inconsequential. Hence when a wife was divorced she had a right to take her personal effects with her but these were simple tools and other artifacts. As noted by the Spry Commission, "under the traditional system a wife would rarely acquire any property of her own after marriage though the husband was required to allocate land or cattle to her for her use" (para 177 at p. 54). These were nor rules entitling a divorced wife to a share in the property acquired during the marriage except that she could take crops stored in her granary. Therefore rules of maintenance after divorce or division of property remained for the most part undeveloped.

On the other hand vital resources such as land and livestock were subject to a complex system of interests in which the wider family participated. Consequently a husband did not have a final say on the disposal of such property. To this must be added the fact that social and economic interdependence which existed in traditional society dispensed with the need to make special provisions for a divorced wife. Such a wife was expected to remarry or to return to her father's lineage where she would live until a man proposed her or her children were old enough to assume the responsibility for her upkeep.

During the colonial era the traditional economy underwent major changes. Women became producers of food as well as cash crops and were also active in other new economic undertakings. Their productive activities ceased to be confined to subsistence production and in due course some households were able to accumulate some wealth. The question then was whether or not such wealth could be divided at the time of divorce. Although no rules existed on the matter, husbands were often quick to point out that the wife had no share in the property because her efforts were part of her "wifely duties" under the traditional system. Here tradition was used to deny the wife a share in the property she helped to accumulate. This therefore, is the context in which ongoing debate about "wifely duties" must be placed.

\section{The Creation of Customary Law}

During the colonial period some divorced wives tried to seek the assistance of the colonial courts to secure division of family assets but many of them were unsuccessful. In 
1963 rules of customary law were screated by the post-colonial state in order to give some recognition to the services of the wives. This was the Customary Law (Declaration) Order 1963 (G. N. 279/63). In this respect it provided that a divorced wife of a peasant would "receive a quarter of the annual and/or of the perennial crop, in store and in the field, of the year in which the divorce (decree was granted)". The Declaration Order provided further that divorced wives of traders and other selfemployed persons "shall receive not less than shs. 150/ - in one lump sum" and courts were empowered to raise the sum depending upon the amount of the husband's wealth (Rule 71 (b)). In the case of a civil servant's wife or of anyone receiving a monthly salary, she was entitled to one month's salary.

The significance of these rules does not lie so much in their ability to provide adequately for the divorced wife, rather they are important for their recognition of a wife's right under 'customary law' to recover something at the time of divorce. Hence, inadequate as its provisions were, the Declaration Order represented the first move, albeit a cautious one, by the state towards the regulation of property relations between spouses married under customary law. Court decisions handed down between 1963 and 1971 when the Order was superceded, reflect this cautious policy. For example, in the case of Salim Ramadhani v. Mariam Ikunga, ${ }^{14}$ a former wife petitioned for division of ten bags of paddy which she and her husband had jointly produced, the court awarded her two and half bags representing a quarter of the whole crop. Yet in another case, when the court was asked by a former wife to divide four shambas cultivated jointly by the couple, the court refused. Chief Justice Saidi held that "a wife owe (d) her husband a duty to assist him with his gainful work, whether it be cultivation, shopkeeping, or any other lawful engagement. In the absence of a contribution of capital by the wife, the divorced wife [could] not be treated as a partner in the man's enterprises". ${ }^{15}$

This decision was cited by Mapigano J., to show that it was not part of Tanzania law to award a divorced wife a share in the family assets. Yet as this discussion has shown, the decision in Iddi's case did not follow the provisions of the Declaration Order nor put into account the fact that capital contribution can be in forms other than money. This problem has now been recognised and catered for in section 114 of the Law of Marriage Act, 1971 .

To sum up, at the time of passing the Law of Marriage Act, a peasant wife's contribution in the running of the household was recognized by the Declaration Order even though it did not sufficiently provide for her. All that the courts needed to do was to expand on this by making reasonable awards depending upon the facts of each case and the extent of the wife's contribution. Now the question is whether or not the right of a peasant wife to a fair share in the property jointly acquired has been enhanced by the new law. In so far as section 114 has been applied to a peasant wife, certain trends can be extracted from the decisions of the High Court.

14 (1967) HCD n. 160.

15 Iddi Kunganya v. Ali Mpate (1967) HCD n. 9. 
Where a peasant wife has made monetary contribution towards the acquisition of assets or the setting up of a business, courts have been willing to order division of such assets. ${ }^{16}$ For example, in Omari Oberi v. Maria Nyakagere ${ }^{17}$ Maganga J., dismissed an appeal against the order of a lower court which had awarded a sum of Tshs. $4,400 /-$ to a former wife. There was sufficient evidence that the wife had contributed Tshs. 200/-towards the establishment of a fishing business in 1942 and the said enterprise had been a success. It is in cases where actual financial contribution by the wife is lacking that courts have expressed diverging opinions. Some have accepted the wife's housework as her contribution towards the acquisition of family assets and others have rejected this interpretation arguing that such services are part of a wife's domestic duties. In the case of Hussein Mohamed v. Hadija Mohamed ${ }^{18}$ Makame J., affirmed the order of the lower court which had granted to a former wife a share in the cashew nut shamba jointly cultivated by the spouses. Also in the case of Petro Kidumba v. Alima Sengolo ${ }^{19}$ Mwalusanya SRM., (as he was then) affirmed the lower court's order granting a former wife (married for 24 years) Tshs. 1500/- (being her share in the matrimonial home), two goats and half of the annual crops.

One significant drawback which divorced women have faced since the early 1960s is their inability to put their claims in the language known to the law. This problem has been made worse by the reluctance of judges to relax rules of procedure in favour of these so-called inarticulate claimants. Thus when a divorced wife petitioned for what she called compensation for the period she had been married, the judge could not understand why anyone would claim compensation for having been married. In the judge's view the claim was misconceived and utterly unfounded and he rejected it. ${ }^{20}$

In another case a former wife petitioned for what she called a "salary due to her as a former wife". ${ }^{21}$ The lower court awarded her Tshs. 180/- but this order was overturned on appeal where the former husband successfully argued that it was improper for his former wife to claim from him a salary when she performed these duties as a wife and not as an employee. In yet another case, ${ }^{22}$ a former wife petitioned at a local primary court for a sum of Tshs. 1500/- "as compensation for the period [of six years] she had lived with [her husband] ". The primary court rejected her claim on the ground that she had been responsible for the breakdown of the marriage. She successfully appealed to the District Court but on further appeal by the husband to the High Court the District

16 See Abdallah Shamte v. Mussa (1972) HCD n. 9.

17 Mwanza High Court (PC) Civ. App. No. 181 of 1973 Maganga J. (unrep.).

18 Mtwara High Court (PC) Matr. Civ. App. No. 28 of 1975 Makame J. (unrep.).

19 Dodoma High Court (PC) Civ. App. Nr. 28 of 1975 (unrep.).

20 See Sitihenge v. Jaseli (1971) HCD n. 175 - where Mwakasendo J., stated that: "It is hard to conceive of a more blatant and despicable form of exploitation and [the wife] must be fully aware that no one can be expected to compensate her for having freely and of her own accord married the respondent. Least of all can she expect the respondent to compensate her for performing wifely duties".

21 Martha Robi Timotheo v. Augustino Kinogo Tarime Primary Court Civ. Case No. 130 of 1968.

22 Marwa Kirigiti v. Susana Wankuro Mwanza High Court (PC) Civ. App. No. 304 of 1975 (Maganga J.) (unrep.). 
Court's order was reversed. In the course of his judgement Maganga J., wondered whether the claim had any basis in law. He observed;

"This was not a claim for maintenance. It was for compensation for the period that the parties lived together as husband and wife. Such suit is certainly not maintainable either under the Law of Marriage Act, 1971 or under the Law of Persons contained in the Customary Law (Declaration) Order 1963. Perhaps that is why the assessors who sat with the trial magistrate unanimously [rejected her claim]."

There are many examples of such cases which clearly reflect the inability of the courts to meet this urgent need of divorced peasant women. Although one cannot judge harshly the courts for strictly adhering to the adversary system which is unsuitable for this type of litigants, it appears to me in the interest of justice, that courts ought to be a little more understanding and patient with peasant women petitioners almost all of whom are normally not legally represented. As human beings we all know what such litigants mean when they demand salaries or compensation, but as lawyers we are completely baffled by their language which is unknown to the law.

\section{Conclusion}

The scope of this paper has been deliberately confined to the single question of whether or not the law recognises the services of a housewife, whether in rural or urban conditions, as constituting an effort within the provisions of section 114 of the Law of Marriage Act.

The discussion has inevitably been organized around the decision given in the case of Zawadi Abdallah in which Mapigano J., discussed the issues fully. Due to the particular concerns of this paper, I regret that a number of important issues had to be left open. For example, no definition of family assets has been attempted here nor has the equally complex question of how the court is to determine each spouse's contribution been discussed. These are difficult questions which have been, and continue to be raised in other jurisdictions. ${ }^{23}$

In England for example, the problem of legal recognition of a housewife's domestic services was first raised in 1956 when the Royal Commission on Marriage and Divorce noted that "[i]f on marriage, [a wife] gives up her paid work in order to devote herself to caring for her husband and children, it is unwarrantable hardship when in consequence she finds herself in the end with nothing she can call her own. ${ }^{24}$ In 1965, Sir Jocelyn Simon in a speech to the Law Society argued that in most families "the wife bears and rears children and minds the home. She thereby frees her husband for his economic

23 See for example J. Eekelaar (1979) 'Some Priciples of Financial and Property Adjustment on Divorce 95 Law Quarterly Review 253; O. Kahn-Freund (1979) 'Recent Legislation on Matrimonial Prosperty، 33 Law Quarterly Review 601; J. G. Miller (1970) 'Family Assets 86 Law Quarterly Review 98.

24 (1956) Cmnd. 9678, para 652 at p. 178. 
activities. Since it is her performance of her functions which enables the husband to perform his, she is in justice entitled to share in its fruits. $1{ }^{25}$ Yet as correctly remarked by Lord Denning M. R., courts were unable to do justice to such a wife until 1970 when the law was changed. ${ }^{26}$ Section 5(1) (f) of the Matrimonial Causes Property Act provided the remedy by requiring a court when considering whether to make a transfer of property to have regard inter alia, "to the contributions made by each of the parties to the welfare of the family including any contributions made by looking after the home or caring for the family".

In a country such as England where some couples share housework on a rota basis, it is not entirely obvious that every wife would perform those functions which in Tanzania have come to be labelled 'wifely duties'. For this reason one can understand the reluctance of courts to recognize such duties as being performed exclusively by the wife. But more important is the fact that in England there was no such legislation approaching in terms the provisions of section 114 of the Law of Marriage Act. Here the hands of the English courts were truly tied. As observed by Lord Hudson in the case of Pettit v. Pettit, ${ }^{27}$ "I do not myself see how one can correct the imbalance which may be found to exist in property rights as between husband and wife without legislation".

Unlike England before 1970, Tanzania has passed the necessary legislation and it seems to me pedantic to the extreme to expect the legislature to amend section 114 and rewrite subsection (2) (b) of section 114 to reflect a contribution made by wives which is so notorious that every law maker should know of its existence.

\section{Post Script :}

After this paper was written and submitted for publication, the Court of Appeal of Tanzania decided, on 29th November 1983, in the case of Bi. Hawa Mohamed v. Ally Sefu (Civ. App. No. 9 of 1983), that the words "joint efforts" and "work towards the acquiring of the assets" found in Section 114 of the Law of Marriage Act 1971, must "be construed as embracing the domestic refforts' or 'work' of husband and wife". Their Lordships (Nyalali, C. J., Makame and Kisanga, JJ. A) were of the unanimous view that the object of the Tanzania Law of Marriage Act, was to liberate married women from economic exploitation by reducing the traditional inequality between them and their husbands.

The decision in Bi. Hawa Mohamed therefore has effectively overruled the holding of Mapigano, J. in the case of Zawadi Abdallah while at the same time resolving the disagreement among the High Court judges over whether or not housework is to be

25 The Seven Pillars of Divorce Reform (1965) 62 Law Society Gazette at p. 345 - (cited in Wachtel v. Wachtel at p. 837).

26 In Wachtel v. Wachtel (1973) 1 All E.R. 831 (CA) at p. 838.

27 (1969) 2 All E.R. 385 at 404. 
recognised as entitling a spouse to a share in the family assets. This decision is to be welcomed as a landmark pronouncement from the highest court of the land. It is not only a correct decision from a purely legal position of statutory interpretation, but it is also a decision which properly recognises the economic rights of women most of whom being not salaried workers, used to invest their entire youthful and active years' in the marriage only to be told at divorce that they have no share in the family assets because they were mere wives who performed "wifely duties" for free.

\section{Spendenaufruf}

\section{Humanitäre Einzelfallhilfe für Asylsuchende}

Armenier, Assyrer, Kurden, Yezidi, Eritreer, Oromo, Südsudanesen und Tamilen stehen für viele andere Angehörige unterdrückter Minderheiten, die zu heimatlosen Flüchtlingen geworden sind. Einige von ihnen suchen Schutz in der Bundesrepublik. In den letzten Jahren hat sich ihre soziale Situation weiter verschlechtert.

Um in besonderen Härtefällen schnell und unbürokratisch helfen zu können, hat die Gesellschaft für bedrohte Völker einen Fond errichtet.

Dazu benötigen wir Ihre Unterstützung.

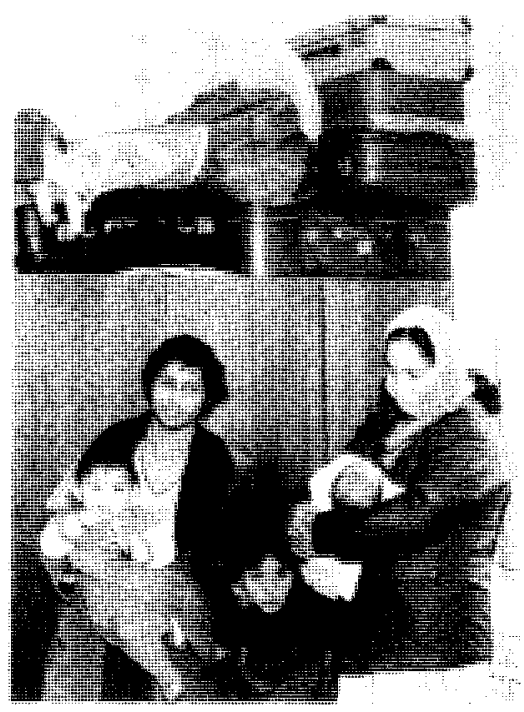

Spenden Sie bitte unter dem Stichwort "Humanitäre Einzelfallhilfe für Asylsuchende" auf das Konto Nr. 7400 der Gesellschaft für bedrohte Völker beim Postscheckamt Hamburg.

Spenden sind steuerlich absetzbar; Spendenquittungen jeweils am Jahresende Gesellschaft für bedrohte Völker, Postfach 2024, 3400 Göttingen, Tel: 0551/55822. 


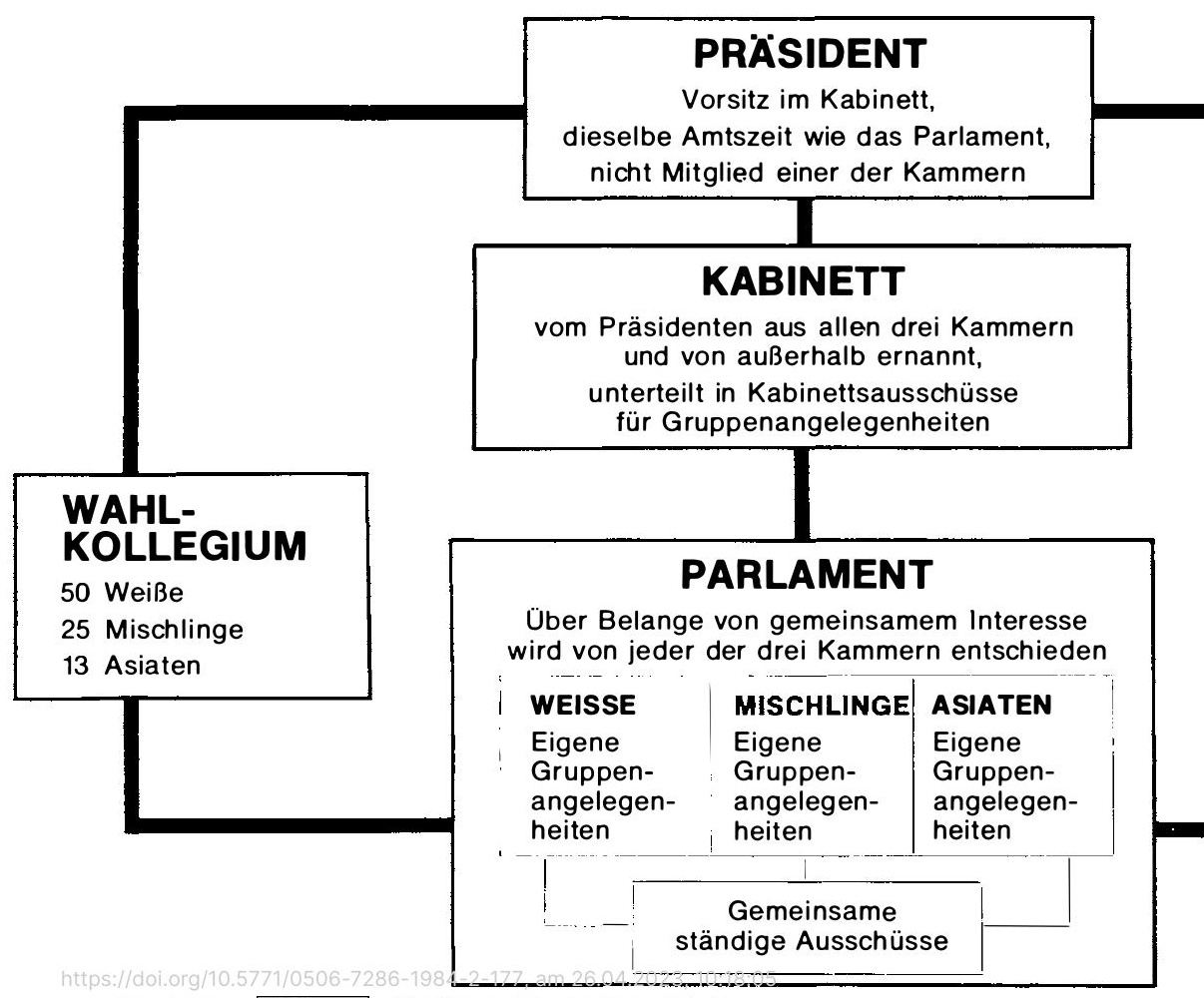

